\title{
4.4 Lethal and sublethal effects of azadirachtin on the bumblebee Bombus terrestris (Hymenoptera: Apidae)
} \\ 1 Department of Crop Protection, Faculty of Bioscience Engineering, Ghent University, Coupure Links 653, \\ 9000, Ghent, Belgium \\ 2 Departamento de Entomologia, Universidade Federal de Viçosa, Av. Peter Henry Rolfs, Viçosa, Minas Gerais, \\ 36570-900, Brazil. Corresponding author:Wagner Faria Barbosa, Tel. +55 (31) 3899-4026, E-mail: \\ barbosawf@gmail.com
}

\section{Abstract}

Background: Lethal and sublethal effects of azadirachtin were studied on Bombus terrestris via oral exposure in the laboratory to bring out the potential risks of the compound to this important pollinator.

Results: Microcolonies chronically exposed to azadirachtin via treated sugar water during 11 weeks in the laboratory exhibited a high mortality ranging from 32 to $100 \%$ with a range of concentrations between 3.2 and $320 \mathrm{mg} \mathrm{litre}^{-1}$. No reproduction was scored at concentrations higher than $3.2 \mathrm{mg} \mathrm{litre}^{-1}$. At $3.2 \mathrm{mg} \mathrm{litre}^{-1}$, azadirachtin significantly inhibited the egg laying and, consequently, the production of drones during 6 weeks. When azadirachtin was tested under an experimental setup in the laboratory where bumblebees need to forage for food, the sublethal effects were stronger as the numbers of drones were reduced already with a concentration of $0.64 \mathrm{mg}$ litre $^{-1}$. Besides, a negative correlation was found between the body mass of male offspring and azadirachtin concentration.

Conclusion: Azadirachtin can affect $B$. terrestris with a range of sublethal effects. This study confirms the need to test compounds on their safety, especially when they have to perform complex tasks such as foraging.

Keywords: chronic oral exposure, insect growth regulator (IGR), neem, repellence effect, reproduction

\section{Introduction}

The use of pesticides has been the major approach in crop protection for decades. ${ }^{1-3}$ Consequently, the concern regarding the risk of pesticide exposure to bee species has been increasing 4,5 , since such compounds may cause a variety of sublethal effects and impair development, reproduction and behaviour of these pollinators. ${ }^{6-10}$ Faced with potential risks of pesticides, a new challenge lies in the search for new compounds that are considered less harmful $^{11}$. In this context, insecticides of natural origin, also called biorational insecticides or bioinsecticides, have received considerable acceptance ${ }^{12}$.

Azadirachtin, a complex tetranortriterpenoid limonoid extracted from seeds of the Indian neem tree Azadirachta indica (Meliaceae) is currently one of the most prominent bioinsecticides available $^{13}$. Because of its natural origin, low mammalian toxicity and fast degradation, the utilization of azadirachtin has been widely encouraged for crop protection ${ }^{14}$. However, azadirachtin is known to possess strong biological properties as feeding deterrent and insect growth regulator $(\mathrm{IGR})^{15}$, which may warrant assessments of the potential risks against beneficial arthropods, especially bees.

The bumblebee species Bombus terrestris is a well-known pollinator of wild flowers and has become economically important since it has been utilized in the commercial pollination of agricultural crops like tomato and strawberry ${ }^{16}$. Until now, there is no study related to the effects of azadirachtin on bumblebees, and the few existing studies were exclusively carried out with Apis mellifera ${ }^{17,18}$. Therefore, in this study we hypothetised that azadirachtin could lead to lethal and sublethal effects on morphology and reproduction of $B$. terrestris. First, microcolonies were exposed to the compound and the effects against bumblebee survival and nest reproduction were 
scored. Second, the impact of azadirachtin on microcolonies were tested for risks when bumblebees needed to forage for their food.

\section{Materials and methods}

\subsection{Insects}

All bumblebees were obtained from a continuous mass-rearing (Biobest, Westerlo, Belgium) and maintained in a room at $30^{\circ} \mathrm{C}, 60 \%$ of relative humidity $(\mathrm{RH})$ and continuous darkness. The insects were fed with commercial sugar water (Biogluc, Biobest) and honeybee-collected pollen (Soc. Coop. Apihurdes, Pinofranqueado-Cáceres, Spain) as energy and protein source, respectively ${ }^{19}$.

\subsection{Chemicals}

Commercial formulations of azadirachtin (Insecticida Natural Neem, BioFlower, Tàrrega, Spain) and imidacloprid (Confidor 200 SL, Bayer CropScience, Machelen, Belgium) were used. Azadirachtin was tested in a series of concentrations above and below the maximum field recommended concentration (MFRC): $32 \mathrm{mg}$ litre ${ }^{-1}$. Imidacloprid was added as reference of drastic effects and tested at $0.02 \mathrm{mg} \mathrm{litre}^{-1}$ because this concentration was reported to affect foraging behaviour in bumblebees $^{19}$. All insecticide solutions were prepared using commercial sugar water (Biogluc) as used in the colony rearing.

\subsection{Chronic bioassay with microcolonies not including foraging behaviour}

A laboratory bioassay was carried out to quantify the lethal effect and reproduction fitness of bumblebee's microcolonies under chronic oral exposure. The microcolonies were made by placing five newly-emerged workers into an artificial plastic nest box $(15 \times 15 \times 10 \mathrm{~cm})$. The microcolonies were fed with plain sugar water via a container of $500 \mathrm{ml}$ under the nest box and pollen inside the nest $^{19}$. After 1 week one worker bumblebee became dominant and started to lay unfertilized eggs that produce only male offspring ${ }^{20}$.

Immediately after the 1-week period, the workers were orally exposed to a range of azadirachtin concentrations via treated sugar water that was placed in a container $(500 \mathrm{ml})$ beneath the artificial nests. Azadirachtin was diluted at $320,64,32,16,6.4$ and $3.2 \mathrm{mg} \mathrm{litre}^{-1}$, corresponding to $10 / 1,2 / 1,1 / 1,1 / 2,1 / 5$ and 1/10 times of the MFRC. The exposure lasted 11 weeks. Plain sugar water was used as control treatment. Imidacloprid was used at $0.02 \mathrm{mg}^{\text {litre }}{ }^{-1}{ }^{19}$. Pollen was replaced twice a week. Eight artificial nests with five workers were used per treatment.

The mortality was assessed every two days and used to estimate survival curves. The sublethal effect on reproduction was monitored on a weekly basis by removing the emerged drones from the microcolonies and counting them. As a measure of sublethal effect, the body mass of the male progeny was also scored by weighing the drones after they had been killed by freezing during 1 hour. The amount of the consumed sugar water was followed by weighing the containers every week; the impact of evaporation was subtracted from the weight loss by assessing the weight of sugar water containers coupled with artificial nests without workers that were placed in parallel with the bioassay under the same environmental conditions.

\subsection{Chronic bioassay with microcolonies including foraging behaviour}

A laboratory bioassay was carried out to assess the impact of lethal and sublethal concentrations of azadirachtin on the performance of bumblebee microcolonies, which included foraging behaviour under laboratory conditions. This was performed following an adapted foraging behaviour bioassay as described by Mommaerts and collaborators ${ }^{19}$. Briefly, two artificial plastic nest boxes $A$ and $B(15 \times 15 \times 10 \mathrm{~cm})$ were connected by a plastic tube $(20 \mathrm{~cm}$ length and $2 \mathrm{~cm}$ of diameter). Five newly emerged workers were placed in box $A$ where they received pollen placed in the box and sugar water via a container $(500 \mathrm{ml})$ placed beneath the box. After eight days, when 
egg laying started in box $A$, the sugar water was removed from box $A$ and replaced underneath box $B$. The workers were then allowed two days to adapt to this new situation. Subsequently, plain sugar water in box B was replaced with treated sugar water.

Azadirachtin was diluted at $32,3.2,0.64,0.32,0.16$ and $0.064 \mathrm{mg} \mathrm{litre}^{-1}$, corresponding to $1 / 1,1 / 10$, $1 / 50,1 / 100,1 / 200,1 / 500$ times of the MFRC. The exposure lasted 11 weeks. Plain sugar water was used as control treatment. Imidacloprid was used at $0.02 \mathrm{mg}_{\text {litre }}{ }^{-1}{ }^{19}$. Pollen was replaced twice a week to avoid unattractive reactions. Eight experimental units (connected boxes A and B with five workers) were used per treatment.

The mortality was assessed every two days and used to estimate survival curves. The sublethal effect on the reproduction was monitored on a weekly basis by counting the number of emerged drones. The body mass of the male progeny was also scored as a measure of sublethal effect. The amount of consumed sugar water was followed by weighing the containers on a weekly basis as already described.

\subsection{Statistical analysis}

The worker's and drone's survival data were subjected to survival analysis using the procedure Survival LogRank in SigmaPlot 12.0 (Systat, San Jose, CA). The survival curves were obtained by Kaplan-Meier estimators and all were pairwise compared using the Bonferroni method. Logistic regression was carried out to the cumulative number of drones using the curve-fitting procedure from SigmaPlot 12.0. Model selection was based on parsimony, high F values (and mean squares), and steep increase in $\mathrm{R}^{2}$ with model complexity. Insect body mass was also subjected either to analysis of variance or regression analysis in SAS. The assumptions of normality and homoscedasticity were checked before data analysis (Proc Univariate, SAS Institute).

\section{Results}

\subsection{Chronic bioassay with microcolonies not including foraging behaviour}

Survival of bumblebee workers was significantly different among azadirachtin concentrations (Log-Rank test: $X^{2}=369.28$, d.f. $=7, p<0.001$ ). The survival curve of azadirachtin at $3.2 \mathrm{mg}$ litre ${ }^{1}$ was similar to both control $(p=0.43)$ and imidacloprid at $0.02 \mathrm{mg} \mathrm{litre}^{-1}(p=0.15)$ curves. A strong effect was observed for insects exposed to azadirachtin at $320 \mathrm{mg} \mathrm{litre}^{-1}$ with complete mortality $(100 \%)$ around 2 weeks (15 days) of exposure (Fig. 1). After 11 weeks of exposure, survival rates were below $30 \%$ for insects exposed to azadirachtin concentrations between 6.4 and $320 \mathrm{mg}$ litre '. Survival rates were above $50 \%$ only for insects exposed to the lowest concentration of azadirachtin (3.2 $\left.\mathrm{mg} \mathrm{litre}^{-1}\right)$, imidacloprid at $0.02 \mathrm{mg} \mathrm{litre}^{-1}$ and control treatment (Fig. 1). 


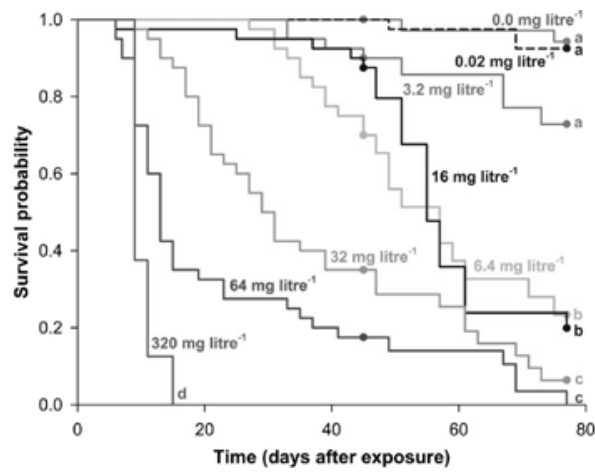

Figure 1 Survival plots of bumblebee workers (Bombus terrestris) chronically exposed to a series of azadirachtin concentrations via treated sugar water. Data originated from chronic bioassay without foraging behaviour. Untreated sugar water (control) is represented by a grey solid curve; imidacloprid at $0.02 \mathrm{mg}$ litre $^{-1}$ is represented by a red dashed curve. Same letters at the end of survival curves indicate no significant difference by Bonferroni method $(p>$ 0.05). Closed circle indicates censured data.

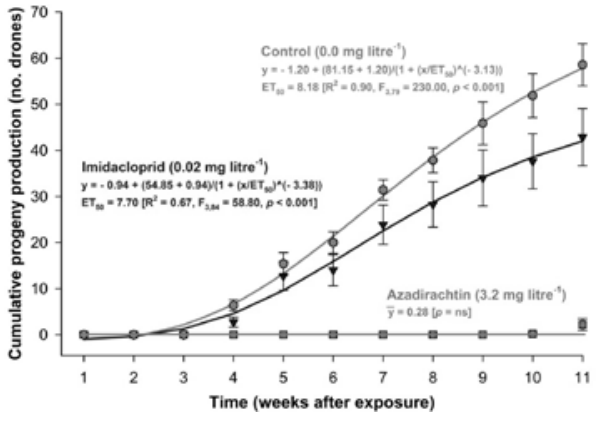

Figure 2 Reproduction of bumblebee (Bombus terrestris) chronically exposed to azadirachtin via treated sugar water. Untreated sugar water (control) is represented by a grey solid curve; imidacloprid at $0.02 \mathrm{mg} \mathrm{litre}^{-1}$ is represented by a red solid curve. $\mathrm{ET}_{50}$ represents median effective time and vertical bars represent standard errors.

A negative effect of azadirachtin was also observed on bumblebee reproduction. No male offspring was produced in the microcolonies exposed to azadirachtin concentrations above $6.4 \mathrm{mg}$ litre $^{-1}$ during the 11 weeks of assessment. Drone production was only observed in microcolonies exposed to the control treatment, imidacloprid at $0.02 \mathrm{mg} \mathrm{litre}^{-1}$ and azadirachtin at $3.2 \mathrm{mg}$ litre $^{-1}$. However, the number of drones produced with imidacloprid at $0.02 \mathrm{mg}$ litre ${ }^{1}(42.9 \pm 4.7)$ and azadirachtin at $3.2 \mathrm{mg} \operatorname{litre}^{-1}(2.2 \pm 1.0)$ was lower than the control $(58.6 \pm 3.3)$. Azadirachtin at $3.2 \mathrm{mg} \mathrm{litre}^{-1}$ also inhibited the appearance of the male progeny in 6 weeks (Fig. 2).

Azadirachtin at $3.2 \mathrm{mg}$ litre ${ }^{-1}$ reduced the body weight of the male progeny $(0.17 \mathrm{~g} \pm 0.01)$ when compared to the control $(0.25 \mathrm{~g} \pm 0.01)(p<0.001)$ (Fig. 3). 


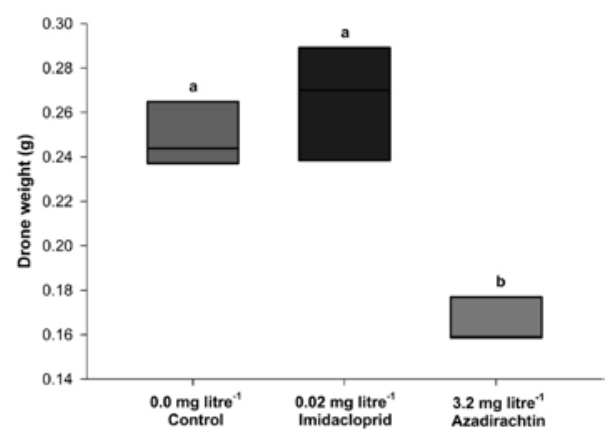

Figure 3 Body mass of the male progeny produced in microcolonies of bumblebees (Bombus terrestris) chronically exposed to azadirachtin via treated sugar water. Data originated from chronic bioassay without foraging behaviour. Untreated sugar water (control) is represented by a grey box blot; imidacloprid at $0.02 \mathrm{mg} \mathrm{litre}^{-1}$ is represented by a red box blot. Boxes followed by the same letter indicate that means (line within the box) were not significantly different by Tukey's HSD test $(p<0.05)$

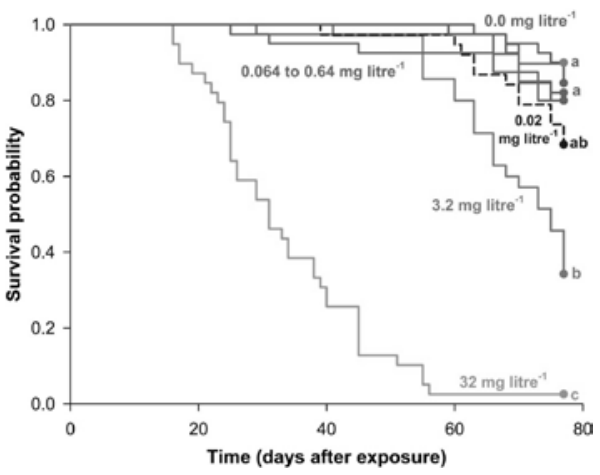

Figure 4 Survival plots of bumblebee workers (Bombus terrestris) exposed to azadirachtin via treated sugar water. Data originated from chronic bioassay with foraging behaviour. Untreated sugar water (control) is represented by a grey solid curve; imidacloprid at $0.02 \mathrm{mg} \mathrm{litre}^{-1}$ is represented by a red dashed curve. Same letters at the end of survival curves indicate no significant difference by Bonferroni method $(p>0.05)$. Closed circle indicates censured data.

The sugar water consumption by the bumblebee workers in the control group started with $1.85 \pm 0.06 \mathrm{~mL}$ per worker and exhibited a peak of $3.21 \pm 0.12 \mathrm{ml}$ per worker at the 4 th week after exposure, matching the peak in reproduction. In contrast, the consumption of sugar water solution contaminated with azadirachtin at $3.2 \mathrm{mg} \mathrm{litre}^{-1}$ remained stable throughout the experiment $(1.53 \pm 0.08 \mathrm{ml}$ per worker), while for higher azadirachtin concentrations (i.e., above $6.4 \mathrm{mg}$ litre $^{-1}$ ) there was a steady decrease in consumption. Such decline was larger for azadirachtin concentrations of 16,32 and $64 \mathrm{mg} \mathrm{litre}^{-1}$, which started with $1.44 \pm 0.15 \mathrm{ml}$ per worker and ended with $0.17 \pm 0.09 \mathrm{~mL}$ per worker, thus reaching nearly $88 \%$ of decrease throughout the weeks until the end of the experiment. For azadirachtin at $320 \mathrm{mg} \mathrm{litre}^{-1}$, the sugar water consumption was restricted to $0.36 \pm 0.00 \mathrm{ml}$ per worker at the first two weeks after exposure when workers were still alive.

\subsection{Chronic bioassay with microcolonies including foraging behaviour}

A significant impaired effect occurred on the survival when bumblebee workers were exposed to increasing concentrations of azadirachtin in the experiment exploring foraging behaviour (LogRank test: $x^{2}=411.447$, d.f. $\left.=7, p<0.001\right)$. At this time, the survival curve of azadirachtin at $3.2 \mathrm{mg}$ litre $^{-1}$ was significantly lower $(p<0.001)$ than the control curve but was similar $(p=0.09)$ to imidacloprid at $0.02 \mathrm{mg} \mathrm{litre}^{-1}$. The survival curves of azadirachtin concentrations between 0.064 and $0.64 \mathrm{mg} \mathrm{litre}^{-1}$ were also similar $(p>0.05)$ to the control treatment (Fig. 4).

Sublethal effect on the bumblebee reproduction appeared as an absence or reduction in the number of the male progeny when microcolonies were exposed to even the lowest azadirachtin concentrations in the bioassay exploring foraging behaviour. A Gaussian regression model was estimated in order to show the pattern of the male progeny production using azadirachtin concentration and time as the independent variables $\left(F_{4,556}=1067.11, p<0.001\right)$ (Fig. 5A). 


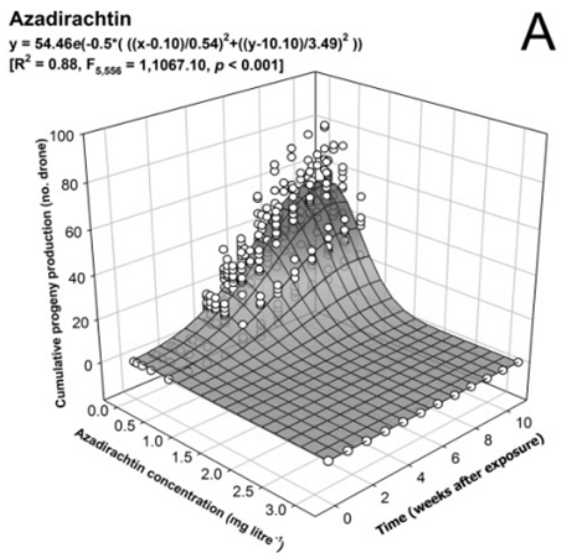

A

B
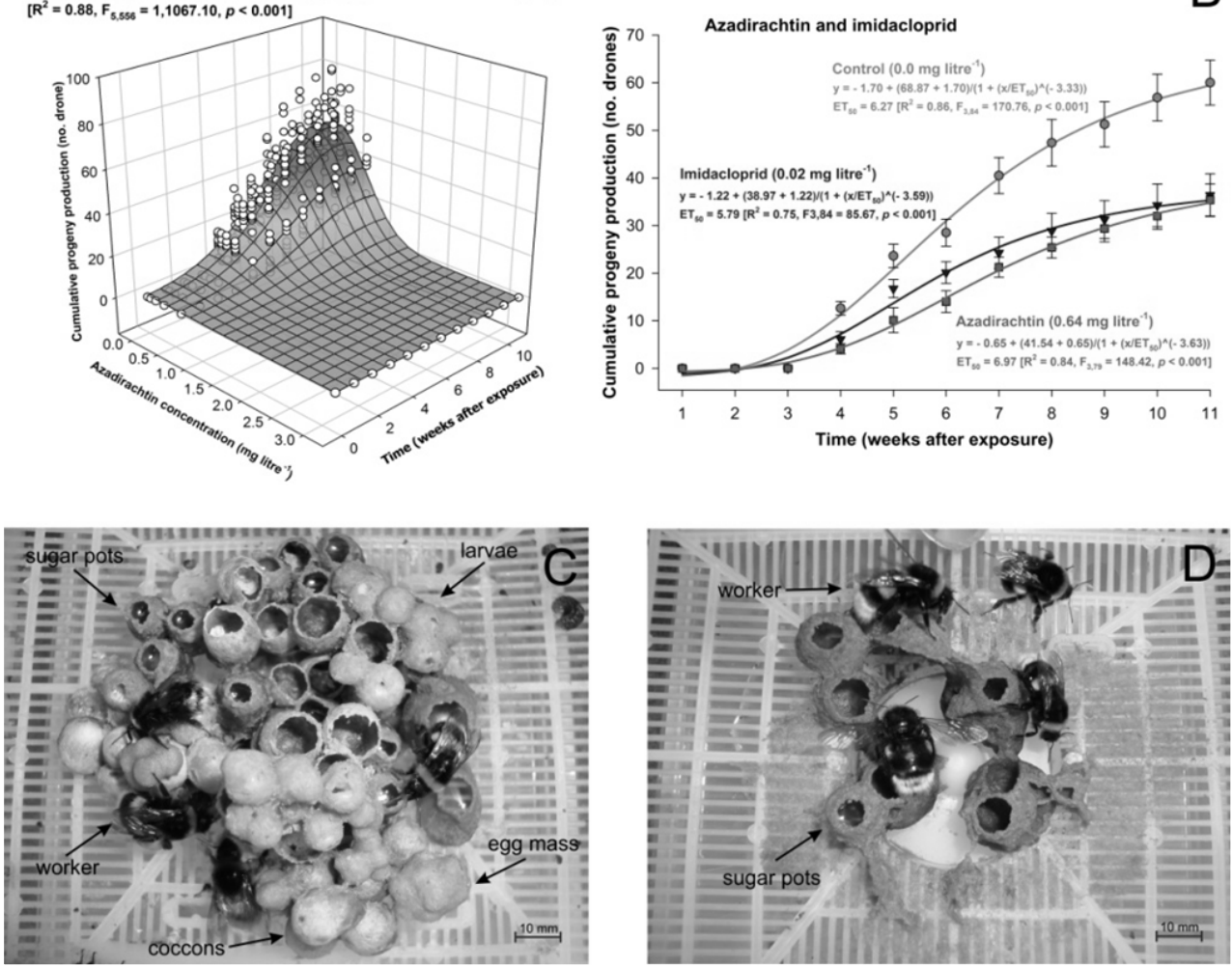

Figure 5 Reproduction and overview of the nests of bumblebees (Bombus terrestris) chronically exposed to a series of azadirachtin concentrations via treated sugar water. Data originated from chronic bioassay with foraging behaviour. (A) A Gaussian regression model representing the progeny production during azadirachtin exposure. (B) Logistic regression models representing the progeny production during exposure to azadirachtin at $0.64 \mathrm{mg}$ litre l. $^{-1}$ Untreated sugar water (control) is represented by a grey solid curve; imidacloprid at $0.02 \mathrm{mg}$ litre $^{-1}$ is represented by a red solid curve. $E T_{50}$ represents the median effective time and vertical bars represent standard errors. (C) A well-constructed bumblebee nest from the control treatment with sugar pots and all immature phases of the male progeny. (D) A badly-constructed bumblebee nest from the treatment with azadirachtin at $3.2 \mathrm{mg}^{\text {litre }}{ }^{-1}$ where only few sugar pots were constructed and no eggs were laid. Nests were photographed 7 weeks after the exposure.

The number of drones produced varied slightly throughout the weeks for azadirachtin concentrations between 0.0 (control) to $0.32 \mathrm{mg}$ litre $^{-1}$ (Fig. 5A). At the concentration of $0.64 \mathrm{mg}$ litre $^{-1}$, the male progeny production throughout the weeks was lower than the control treatment (Fig. 5B). For azadirachtin at 3.2 and $32 \mathrm{mg} \mathrm{litre}^{-1}$, no drone production was observed (Fig. 5A); also poorly developed broods with only few and incomplete sugar pots were observed in these concentrations (Fig. 5D), which contrasts with the control nests (Fig. 5C). Body mass of the male progeny was also negatively affected by azadirachtin $\left(F_{3,36}=27.49, p<0.001\right)$ (Fig. 6). Imidacloprid at $0.02 \mathrm{mg}_{\text {litre }} \mathrm{f}^{-1}$ also impaired the body mass of the male progeny compared to the control treatment $(p<0.05)$ (Fig. 6). 


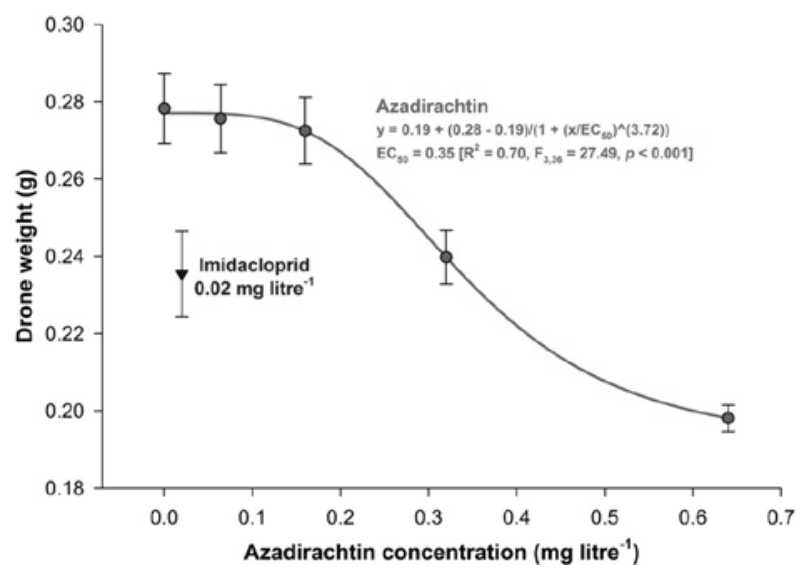

Figure 6 Body mass of the male progeny produced in microcolonies of bumblebees (Bombus terrestris) exposed to increasing concentrations of azadirachtin via treated sugar water. Data originated from chronic bioassay with foraging behaviour.

The sugar water consumption by the bumblebee workers started with $2.68 \pm 0.03 \mathrm{~mL}$ per worker and exhibited a peak of $4.10 \pm 0.13 \mathrm{ml}$ per worker at the 4th week after exposure, matching the peak in reproduction, when the solution was uncontaminated or contaminated with azadirachtin at concentrations lower than $3.2 \mathrm{mg} \mathrm{litre}^{-1}$. In contrast, the consumption of sugar water solution contaminated with azadirachtin at $3.2 \mathrm{mg} \mathrm{litre}^{-1}$ started with $2.58 \pm 0.08 \mathrm{ml}$ per worker and ended with $0.76 \pm 0.19 \mathrm{ml}$ per worker, thus reaching nearly $71 \%$ of decrease throughout the weeks until the end of the experiment. For azadirachtin at $32 \mathrm{mg} \mathrm{litre}^{-1}$, the consumption of sugar water solution started with $2.00 \pm 0.10 \mathrm{ml}$ per worker but at the end of the experiment it was only $0.02 \pm 0.00 \mathrm{ml}$ per worker.

\section{Discussion}

The survival of adult bumblebees was negatively correlated to the azadirachtin concentration in both experiments with and without foraging behaviour. This change in the workers' survival profile can be explained by an exchange between the well-known gustatory and physiological antifeedant effects of azadirachtin on insects ${ }^{21-26}$. The gustatory antifeedancy immediately stops the utilization of the energy source (sugar water) because it blocks the food intake, while the physiological antifeedancy has a palliative impact reducing the food intake and/or uptake ${ }^{21-26}$. Therefore, the fast decline of the survival in worker bumblebees exposed to high concentrations of azadirachtin may be due to the gustatory antifeedancy that blocked the food intake. Indeed, bumblebee workers, as for hymenoptera in general, are more sensitive to the gustatory antifeedancy only in high concentrations. Without sugar water, worker bumblebees cannot survive more than two days after starvation as we observed in a small extra experiment. However, individuals exposed to high concentrations of azadirachtin (for instance, 64 and $320 \mathrm{mg}^{\text {litre }}{ }^{-1}$ ) started to die nearly 10 days after exposure. This was probably because workers were able to feed on the untreated sugar water as stored in the nest pots before the exposure allowing them to survive more than 2 days. On the other hand, individuals that showed a prolonged survival when exposed to the other concentrations may have had a better use of the energy source because they were sensitive only to the secondary antifeedant effect of azadirachtin. Apart from the antifeedant effects, azadirachtin has a range of cytotoxic effects such as interference with cell division, vacuolization of the cytoplasm and breakdown of protein synthesis in a variety of insect tissues $^{27,28}$, which may have contributed to impair the integrity of the workers' living body.

In addition to the lethality, sublethal effects were also recorded on bumblebee microcolonies. The impact on reproduction, for instance, was quite severe when microcolonies were chronically 
exposed to azadirachtin. First, azadirachtin was able to reduce or completely block the production of drones depending on the concentration used. Azadirachtin has sterilizing activity among different insect species ${ }^{29,30}$. This effect is generally attributed to disturbances in the synthesis or release of hormones or neurohormones involved in the insect reproduction ${ }^{31,32}$. In bumblebees, as well as in distinct insect species, juvenile hormone $(\mathrm{JH})$ and ecdysteroids are the main hormones linked to the behavioural and physiological aspects of the reproduction ${ }^{33,34}$. Such hormonal disturbances caused by azadirachtin are in general linked to damages on ovarian development or related processes ${ }^{35,36}$. These impairments include blockage of oogenesis, disruption of vitellogenesis and vitelline envelope formation, degeneration of follicle cells and breakdown of yolk protein production ${ }^{29,35}$. However, since azadirachtin has antifeedant effects against insects, the impact on ovarian development and consequently reproduction may be additionally attributed to a low food intake or uptake. In our experiments, for instance the consumption of sugar water per worker decreased nearly $90 \%$ throughout the weeks with azadirachtin at 16, 32 and $64 \mathrm{mg} \mathrm{litre}^{-1}$. Therefore, these reductions in sugar water consumption may indicate that the antifeedant effect possibly also contributed to the increased severity of the impairment caused by azadirachtin on bumblebee reproduction.

It is worth to mention that the support, given by the subordinate workers to the dominant worker in order to reproduce, became much lower as the survival was impaired over time by azadirachtin. The reduced number of workers impaired the construction of the nest and in turn, this may affect the egg laying of the dominant worker. However, in our experiments the egg laying was immediately blocked after the oral exposure to concentrations of azadirachtin above of $3.2 \mathrm{mg}$ litre $^{-1}$; this indicates that the impairment on reproduction was mainly due to physiological effects trigged by azadirachtin on the dominant worker, but not due to the lack of subordinated workers to support them.

We observed that egg laying was restored in the treatment with azadirachtin at $3.2 \mathrm{mg} \mathrm{litre}^{-1}$ in the laboratory experiment without foraging behaviour. At this concentration, larvae were also able to complete their development and drones emerged. In this case, the recovery of reproduction measured as male progeny production, is probably related to the degradation of azadirachtin through time, which may have reduced poisoning, allowing egg laying and ensuring survival of the dominant workers and larvae, respectively. Azadirachtin kept into aqueous solutions and under low ultra-violet (UV) condition shows much less degradation when compared with dry surfaces and under high UV condition ${ }^{37,38}$. This probably contributed to the delay in 6 weeks of the egg laying of the dominant worker exposed to azadirachtin at $3.2 \mathrm{mg} \mathrm{litre}^{-1}$ in the laboratory bioassay without foraging behaviour. Second, reproduction probably was also restored due to the production of detoxifying enzymes and/or excretion of the compound allowing the recovery of the impaired physiological systems associated with the oviposition.

Sublethal effects of azadirachtin were also expressed as a reduction in the body mass of the adult male offspring. This is probably because the progeny underwent the physiological antifeedant effect of azadirachtin during its larval stages. Therefore, treated larvae may have eaten less than larvae from the control. In insects, bad nutrition, starvation, or restriction of food during larval stages may force pupation before the achievement of an ideal species-specific weight given rise to smaller adult individuals ${ }^{39,40}$. For imidacloprid, we believe that reduction of body mass of male progeny was due to impairment of the foraging behaviour. This was because imidacloprid reduced the weight of the drones only in the chronic bioassay including foraging behaviour. Impact on foraging probably led to an indirect effect in the care of the offspring because the collection of food was reduced and consequently the supplying to the larvae. Imidacloprid is a well-known neonicotinoid insecticide that acts as agonist of nicotinic acetylcholine receptors (nAChR) leading to hyperexcitation of neurons $\mathrm{s}^{41,42}$. Due to its neurotoxic character, imidacloprid may impair learning, memory and foraging behaviour of bee species ${ }^{43,44}$. Thus, the impact on the drone body mass could only be observed in the laboratory experiment that included the possibility to perform foraging behaviour. For many insects body mass or size of males may 
interfere with the mating dynamics, sexual selection, reproductive potential and/or progeny production) ${ }^{45-47}$. Therefore, measures on body mass or size in the male progeny of bumblebees become an important sublethal effect.

Putting the data together from both chronic toxicity bioassays with and without foraging behaviour, we can infer that the inclusion of foraging behaviour in the experimental setup increases the overall lethal and sublethal effects of the compound tested. For instance, the survival of bumblebee workers was lower with azadirachtin at $3.2 \mathrm{mg}^{\text {litre }}{ }^{-1}$ and imidacloprid at $0.02 \mathrm{mg}$ litre $^{-1}$ when foraging behaviour was included in the setup. In addition, egg laying was completely blocked during 11 weeks of exposure to azadirachtin at $3.2 \mathrm{mg} \mathrm{litre}^{-1}$ when foraging behaviour was included in the setup. For imidacloprid, the body mass of the male progeny was impaired only when foraging was included in the setup. With the same laboratory behavioural setup for chronic toxicity, Mommaerts and collaborators also found that the impairment by imidacloprid on lethal and sublethal traits was higher when foraging behaviour was included ${ }^{19}$. Therefore, the results as shown here reinforce the need to increase the complexity of the experimental setup with foraging behaviour in order to ensure better outcomes in studies of risk assessment in $B$. terrestris what is also in accordance with the new guidance document of the European Food Safety Authority ${ }^{8}$. It is constantly stated in the literature that azadirachtin is safe for beneficial arthropods ${ }^{13}$; although our results have shown that the compound may affect $B$. terrestris with a range of sublethal effects, which are very important for the development and survival of the colonies. Here it should be remarked that, although the effects of this study were found under laboratory conditions with long-term chronic exposure which are unexpected under semi-field or field conditions with the low residual potential persistence of azadirachtin in these situations ${ }^{38,48}$, Africanized honeybees ( $A$. mellifera) have been found to undergo lethal and sublethal effects on adult and larval individuals in their colonies when the foragers start to pollinate the Indian neem tree (A. indica), the plant from which azadirachtin is obtained ${ }^{49}$. The latter findings may indicate that the effects as observed upon chronic exposure to azadirachtin are conserved among bee pollinators and thus should not be neglected. For a better understanding of the effects caused by azadirachtin, we suggest that future semi-field and field studies should be performed considering situations that may include acute and chronic exposure in the risk assessment setup.

\section{References}

1 Metcalf RL, Changing role of insecticides in crop protection. Annu Rev Entomol 25:219-255 (1980).

2 Cooper J, Dobson H, The benefits of pesticides to mankind and the environment. Crop Prot 26:1337-1348 (2007).

3 Lamberth C, Jeanmart S, Luksch T, Plant A, Current challenges and trends in the discovery of agrochemicals. Science 341:742746 (2013).

4 Gill RJ, Ramos-Rodriguez O, Raine NE, Combined pesticide exposure severely affects individual- and colony-level traits in bees. Nature 491:105-119 (2012).

5 Johnson RM, Dahlgren L, Siegfried BD, Ellis MD, Acaricide, fungicide and drug interactions in honey bees (Apis mellifera). PLoS ONE 8:e54092 (2013).

6 Wu JY, Anelli CM, Sheppard WS, Sub-lethal effects of pesticide residues in brood comb on worker honey bee (Apis mellifera) development and longevity. PLOS ONE 6:e14720 (2011).

7 Blacquiere T, Smagghe G, Van Gestel CAM, Mommaerts V, Neonicotinoids in bees: a review on concentrations, side-effects and risk-assessment. Ecotoxicology 21:973-992 (2012).

8 European Food Safety Authority, Scientific opinion on the science behind the development of a risk assessment of plant protection products on bees (Apis mellifera, Bombus spp. and solitary bees). EFSA J 10:2668 (2012).

9 Bryden J, Gill RJ, Mitton RAA, Raine NE, Jansen VAA, Chronic sublethal stress causes bee colony failure. Ecol Lett 16:1463-1469 (2013).

10 Smagghe G, Deknopper J, Meeus I, Mommaerts V, Dietary chlorantraniliprole suppresses reproduction in worker bumblebees. Pest Manag Sci 69:787-791 (2013).

11 Villaverde JJ, Sevilla-Moran B, Sandin-Espana P, Lopez-Goti C, Alonso-Prados JL, Biopesticides in the framework of the European Pesticide Regulation (EC) No. 1107/2009. Pest Manag Sci 70:2-5 (2014).

12 Cantrell CL, Dayan FE, Duke SO Natural products as sources for new pesticides. J Natural Prod 75:1231-1242 (2012).

13 Boeke SJ, Boersma MG, Alink GM, van Loona JJA, van Huis A, Dicke M, Rietjens IMCM, Safety evaluation of neem (Azadirachta indica) derived pesticides. JEthnopharmacol 94:25-41 (2004). 
14 Isman MB, Botanical insecticides, deterrents, and repellents in modern agriculture and an increasingly regulated world. Annu Rev Entomol 51:45-66 (2006).

15 Morgan ED Azadirachtin, a scientific gold mine. Bioorgan Med Chem 17:4096-4105 (2009).

16 Velthuis HHW, van Doorn A, A century of advances in bumblebee domestication and the economic and environmental aspects of its commercialization for pollination. Apidologie 37:421-451 (2006).

17 Melathopoulos AP, Winston ML, Whittington R, Smith T, Lindberg C, Mukai A, Moore M, Comparative laboratory toxicity of neem pesticides to honey bees (Hymenoptera: Apidae), their mite parasites Varroa jacobsoni (Acari: Varroidae) and Acarapis woodi (Acari: Tarsonemidae), and brood pathogens Paenibacillus larvae and Ascophaera apis. J Econ Entomol 93:199-209 (2000).

18 Thompson HM, Wilkins S, Battersby AH, Waite RJ, Wilkinson D, The effects of four insect growth-regulating (IGR) insecticides on honeybee (Apis mellifera L.) colony development, queen rearing and drone sperm production. Ecotoxicology 14:757769 (2005).

19 Mommaerts V, Reynders S, Boulet J, Besard L, Sterk G, Smagghe G, Risk assessment for side-effects of neonicotinoids against bumblebees with and without impairing foraging behavior. Ecotoxicology 19:207-215 (2010).

20 Michener CD, The social behaviour of the bees. Harvard University Press, Cambridge (1974).

21 Mordue (Luntz) AJ, Nisbet AJ, Azadirachtin from the neem tree Azadirachta indica: its action against insects. An Soc Entomol Brasil 29:615-632 (2000).

22 Mordue (Luntz) AJ, Simmonds MSJ, Ley SV, Blaney WM, Mordue W, Nasiruddin M, Nisbet AJ, Actions of azadirachtin, a plant allelochemical, against insects. Pest Sci 54:277-284 (1998).

23 Blaney WM, Simmonds MSJ, Ley WV, Anderson JC, Toogood PL, Antifeedant effects of azadirachtin and structurally related compounds on lepidopterous larvae. Entomol Exp App/ 55:149-160 (1990).

24 Simmonds MSJ, Blaney WM, Ley SV, Anderson JC, Banteli R, Denholm AA, Green PCW, Grossman RB, Gutteridge C, Jennens L, Smith SC, Toogood PL, Wood A, Behavioral and neurophysiological responses of Spodoptera littoralis to azadirachtin and a range of synthetic analogs. Entomol Exp Appl 77:69-80 (1995).

25 Timmins WA, Reynolds SF, Azadirachtin inhibits secretion of trypsin in midgut of Manduca sexta caterpillars: reduced growth due to impaired protein digestion. Entomol Exp Appl 63:47-54 (1992).

26 Trumm P, Dorn A, Effects of azadirachtin on the regulation of midgut peristalsis by the stomatogastric nervous system in Locusta migratoria. Phytoparasitica 28:7-26 (2000).

27 Salehzadeh A, Jabbar A, Jennens L, Ley SV, Annadurai RS, Adams R, Strang RH, The effects of phytochemical pesticides on the growth of cultured invertebrate and vertebrate cells. Pest Manag Sci 58:268-276 (2002).

28 Sayah F, Ultrastructural changes in the corpus allatum after azadirachtin and 20-hydroxyecdysone treatment in adult females of Labidura riparia (Dermaptera). Tissue Cell 34:53-62 (2002).

29 Sayah F, Idaomar M, Soranzo L, Karlinsky A, Endocrine and neuroendocrine effects of azadirachtin in adult females of the earwig Labidura riparia. Tissue Cell 30:86-94 (1998).

30 Arno J, Gabarra R, Side effects of selected insecticides on the Tuta absoluta (Lepidoptera: Gelechiidae) predators Macrolophus pygmaeus and Nesidiocoris tenuis (Hemiptera: Miridae). J Pest Sci 84:513-520 (2011).

31 Dorn A, Rademacher JM, Sehn E, Effects of azadirachtin on the moulting cycle, endocrine system and ovaries in last-instar larvae of the milkweed bug, Oncopeltus fasciatus. J Insect Physiol 32:231-238 (1986).

32 Barnby MA, Klocke JA, Effects of azadirachtin on levels of ecdysteroids and prothoracicotropic hormone-like activity in Heliothis virescens (Fabr.) larvae. J Insect Physiol 36:125-131 (1990).

33 Bloch G, Borst DW, Huang Z-Y, Robinson GE, Cnaani J, Hefetz, A Juvenile hormone titers, juvenile hormone biosynthesis, ovarian development and social environment in Bombus terrestris. J Insect Physiol 46:47-57 (2000a).

34 Bloch G, Hefetz A, Hartfelder K, Ecdysteroid titer, ovary status, and dominance in adult worker and queen bumble bees (Bombus terrestris). J Insect Physiol 46:1033-1040 (2000b).

35 Sayah F, Fayet C, Idaomar M, Karlinsky A, Effects of azadirachtin on vitellogenesis of Labidura riparia (Insecta: Dermaptera). Tissue Cell 28:741-749 (1996).

36 Lucantoni L, Giusti F, Cristofaro M, Pasqualini L, Esposito F, Lupetti P, Habluetzel A, Effects of a neem extract on blood feeding, oviposition and oocyte ultrastructure in Anopheles stephensi Liston (Diptera: Culicidae). Tissue Cell 38:361-371 (2006).

37 Thompson DG, Kreutzweiser DP, Staznik B, Chartrand D, Capell S, Fate and persistence of azadirachtin a following applications to mesocosms in a small forest lake. Bull Environ Contam Toxicol 69:250-256 (2002).

38 Kumar P, Poehling H-M, Persistence of soil and foliar azadirachtin treatments to control sweetpotato whitefly Bemisia tabaci Gennadius (Homoptera: Aleyrodidae) on tomatoes under controlled (laboratory) and field (netted greenhouse) conditions in the humid tropics. J Pest Sci 79:189-199 (2006).

39 Munyiri FN, Asano W, Shintani Y, Ishikawa Y, Threshold weight for starvation-triggered metamorphosis in the yellowspotted longicorn beetle, Psacothea hilaris (Coleoptera: Cerambycidae). Appl Entomol Zool 38:509-515 (2003).

40 Chen Y, Ruberson JR, Starvation effects on larval development of beet armyworm (Lepidoptera: Noctuidae). J Entomol Sci 43:247-253 (2008).

41 Cassida JE, Quistad GB, Why insecticides are more toxic to insects than people: the unique toxicology of insects. J Pestic Sci 29:81-86 (2004).

42 Jeschke P, Nauen R, Neonicotinoids_from zero to hero in insecticide chemistry. Pest Manag Sci 64:1084-1098 (2008). 
43 Decourtye A, Armengaud C, Renou M, Devillers J, Cluzeau S, Gauthier M, Pham-Delegue MH, Imidacloprid impairs memory and brain metabolism in the honeybee (Apis mellifera L.). Pestic Biochem Physiol 78:83-92 (2004).

44 Yang EC, Chuang YC, Chen YL, Chang LH, Abnormal foraging behavior induced by sublethal dosage of imidacloprid in the honey bee (Hymenoptera: Apidae). J Econ Entomol 101:1743-1748 (2008).

45 Zanuncio JC, Molina-Rugama AJ, Santos GP, Ramalho FD, Effect of body weight on fecundity and longevity of the stinkbug predatorPodisus rostralis. Pesqui Agropecu Bras 37:1225-1230 (2002).

46 Schluns H, Schluns EA, van Praagh J, Moritz RFA, Sperm numbers in drone honeybees (Apis mellifera) depend on body size. Apidologie 34:577-584 (2003).

47 Amin MR, Bussière LF, Goulson D, Effects of male age and size on mating success in the bumblebee Bombus terrestris. Insect Behav 25:362-374 (2012).

48 Kovacova J, Hrbek V, Kloutvorova J, Kocourek V, Drabova L, Hajslova J, Assessment of pesticide residues in strawberries grown under various treatment regimes. Food Addit Contam Part A Chem Anal Control Expo Risk Assess 30:2123-2135 (2013).

49 Alves JE, Toxicidade do nim (Azadirachta indica A. Juss.: Meliaceae) para Apis mellifera e sua importância apícola na Caatinga e Mata Litorânea cearense. Thesis, Universidade Federal do Ceará (2010). 